\title{
Mutualising sunshine: economic and territorial entanglements in a local photovoltaic project
}

\author{
Béatrice Cointe \\ CIRED, UMR 8568 CNRS - Ecole des Ponts ParisTech, EHESS, AgroParisTech, CIRAD, Nogent-sur- \\ Marne, France \\ LAMES, Aix-Marseille Univ, UMR 7305 CNRS, Aix-en-Provence, France \\ cointe@centre-cired.fr \\ $+33669353061$ \\ orcid.org/0000-0002-3647-8327
}

Published online in Local Environment (2018), special Issue "Unlocking Energies, unpacking the entanglements and temporalities of local initiatives".

Cite as:

Béatrice Cointe (2018). Mutualising sunshine: economic and territorial entanglements in a local photovoltaic project. Local Environment. doi: 10.1080/13549839.2018.1436044

\begin{abstract}
:
Focusing on a successful local photovoltaic project in France, this paper retraces the emergence and constitution of a territorial capacity to take part in the development of renewable energy as driven by a private actor (an agricultural cooperative) that relied on the combination of policy support, of a tradition of mutualisation, and of its territorial implantation. A relational perspective on innovation and entrepreneurship is adopted to describe the various entanglements that hold this project together. The development of a local renewable energy project and its community is seen as a collective endeavour that requires to establish and consolidate relationships between people and things; relationships are negotiated, tested and shaped through series of trials. I pay particular attention to the material and cognitive devices that are used to articulate the market policy framework and the territory (understood as a geographical, patrimonial and social entity), particularly by organising mutualisation. This enables me to explore how supporting policies and the territory are mobilised and enacted in the course of the project, and the extent to which both are transformed in the process. Supporting policies are turned into a tool for territorial innovation and development, while the tradition of territorial mutualisation that is constitutive of the cooperative that promoted the project becomes a way to provide access to a market and to maximise and redistribute associated profits. This highlights the entanglements through which a specific conception of equity is enacted in a project, and redistributive concerns are incorporated into an economics-centred policy device.
\end{abstract}

Keywords: community energy; renewable energy; feed-in tariffs; grassroots innovation; local capacities; mutualisation

This work was supported by the French National Research Agency (ANR) under the program "Sociétés innovantes" [Grant number 2011- SOIN-003-01, project "COLLENER"] and by the Regional Council Ile-de-France, DIM R2DS [Grant number 2010-13].

Disclosure statement: The author has no financial interest or benefit arising from the direct application of research. 


\section{Introduction}

Renewable energy has long been considered to hold a potential for decentralising energy production. The multiplication of local and community renewable energy ${ }^{1}$ initiatives in Europe over the past decades provides a wide empirical basis to explore, interrogate and characterise this potential (e.g. Walker 2008, Seyfang et al. 2013, Nadaï et al. 2015). A dedicated literature has thus explored the various forms that "community" projects can take (Walker and Devine-Wright 2008), investigated the role of grassroots initiatives in sustainability and innovation (Seyfang and Smith 2007, Middlemiss and Parish 2010, Yalçin-Riollet et al. 2014), studied the institutional and organisational changes triggered when local and regional communities respond to renewable energy policy (Moss et al. 2014), or analysed the construction and characteristics of specific projects in terms of social relations (Walker et al. 2009) or exchange flows and modalities of valuation (Rydin et al. 2014).

In the midst of this enthusiasm for the development of local energy initiatives, critiques have been voiced against too narrow a focus on the local and community scale, especially with regards to the UK policy localism (Amin 2005, Catney et al. 2013). This literature warns "against the local trap", that is against the tendency to consider local initiatives as socially just and democratic because they are local (Purcell and Brown 2005, Catney et al. 2013). It also stresses the risk of overlooking the diversity of localities, of their capacities and of their connections to other scales (or lack thereof) (Marvin and Guy 1997). It recalls that not all groups and communities are equally positioned to take advantage of policies that often pay limited consideration to distributional issues and to uneven capacities to react to funding opportunities (Catney et al. 2013, Park 2012).

This calls for detailed analyses of what it takes to develop community renewable energy, and of the practical ways in which sustainability, solidarity and equity concerns can be incorporated in project development in policy contexts that do not always address them directly. To this end, I adopt a relational perspective inspired by actor-network theory (ANT) analyses of innovation and entrepreneurship (Coutouzis and Latour 1986, Akrich 1992, Akrich et al. 2002a, 2002b, Garud and Karnøe 2003, Doganova 2009) to give account of the development of a mutualised photovoltaic plant scattered across roofs of farm buildings in South-western France. The initiative was triggered and made possible by the strong policy support for photovoltaics that existed in France at the time, but managed to transform an incentive to innovation and entrepreneurship into a device for local development and territorial solidarity.

The project was carried out by an agricultural cooperative, and its success hinges on an original articulation of territorial and mutualistic values to the technological possibilities offered by grid-connected photovoltaics and to the financial incentive

\footnotetext{
${ }^{1}$ Seyfang et al. (2013, p. 978), noting the diversity of interpretations that the term "community energy" can hold (Walker and Devine-Wright 2008), use it to refer to the "projects where communities (of place and interest) exhibit a high degree of ownership and control" and benefit collectively from the outcomes.
} 
constituted by the high feed-in tariffs that were at the core of French renewable energy policy (Debourdeau 2011, Cointe 2015). This involved a partial reinterpretation of feedin tariffs so as to turn them into redistributive instruments, thereby incorporating social and equity concerns into a primarily economic instrument. It was inscribed in the continuity of the cooperative's previous projects, all designed to contribute to reviving and sustaining a territory, ${ }^{2}$ while also enabling the cooperative to become an actor in renewable energy locally and, to an extent, beyond (e.g. participation in networks of sustainable community initiatives (interview 4)): it drew on existing capacities and resources while expanding them.

The ANT perspective translates into an attention to the trials, displacements and negotiations that shaped the project, and in particular to the key moments in which success was at stake. It also leads me to consider the project in its connections to and dependence upon broader policies, markets, networks and issues, that is to say the multiple entanglements that it relies upon. I rely on it to describe the organisation of mutualisation as a way to articulate economic and financial considerations to the pursuit of territorial, solidarity and redistribution objectives. How was mutualisation enacted so as to reconcile these potentially conflicting objectives without letting economic consideration overshadow justice and equity concerns? To what extent was it challenged by extant policy frameworks and financing practices, and how did it adapt to these challenges? Can this case shed light on the conditions under which financial and entrepreneurial considerations and objectives in terms of sustainability, equity and solidarity may complement and reinforce each other?

This case is thus relevant to the analysis of justice and equity in sustainability in at least two respects. First, I analyse mutualisation as a strategy to build "practical capabilities" (Park 2012) for acting on energy locally, and so as a way to channel benefits from policy-supported renewable energy production towards a diversity of rural actors and to incorporate equity concerns in a market-based policy scheme that did not take them into account. Second, while it is not explicitly framed in terms of justice or equity, mutualisation serves as a device for inclusion and solidarity and enacts a set of values that are revived through entrepreneurship but reach far beyond financial profit. Its very design builds upon conceptions of equity and solidarity.

In this respect, the description of the project in terms of its multiple entanglements highlights the trials, tensions, reconfigurations and resources that shaped the project. Solidarity and sustainability appear as situated practical endeavours. By focusing on the work and resources required for communities to take advantage of funding and policy incentives (Catney et al. 2013) and on the entanglements of community energy projects and economics (Rydin et al. 2014), this study seeks to clarify the "market relationships, regulations, institutional arrangements, power configurations, and values and norms" necessary to link social empowerment with economic regeneration (Amin 2005, p. 624).

${ }^{2}$ I use the terms "territory" and "territorial" to translate the French words "territoire" and "territorial". The French terms convey a patrimonial aspect that goes beyond the spatial notion of a geographic territory. 
It also contributes to the emerging exploration of joint dynamics of innovation and community (Seyfang and Smith 2007; Hargreaves et al. 2013), and in particular to the understanding of innovations that are not aimed at market deployment and scaling-up.

In the first section, I present my empirical material and explain how I bring together literature on innovation and entrepreneurship and literature on community energy and localism to analyse it. I then move on to the empirical account: the second section focuses on the origins of the project and the resources and experience that it drew upon. In the third section, I retrace the emergence and realisation of the project, considering three concomitant challenges: delimiting the project and its perimeter; turning rooftops into photovoltaic plants; negotiating and maintaining the viability of the project.

\section{Materials and methods}

On the basis of a detailed case study, I retrace a mutualised local renewable energy project from its emergence as an idea to its full operation. I describe how mutualisation, understood as the pooling together of resources and profits, was organised to combine a territorial community and a business model oriented towards the dispatch of electricity on the mass market. To do so, I bring together literature on community energy and STS approaches to technology, innovation and entrepreneurship, drawing mainly from actornetwork theory (Akrich 1992, Akrich et al. 2002a, 2002b, Latour 2005). This leads me to consider the development of a local renewable energy project - in this case, simultaneously a solar park, a financial enterprise, a territorial area, and a group of people organised in a certain way - as a collective endeavour that requires the establishment and consolidation of relationships between people and things. The project gains in reality as these initially tentative relationships are negotiated, tested and shaped through series of trials and displacements.

Indeed, ANT emphasises the relational and distributed character of innovation and entrepreneurship. It has described how ideas are realised through the enrolment of multiple partners, both human and non-human (Coutouzis and Latour 1986, Akrich et al. 2002a, 2002b), in a process that simultaneously shapes and defines the social and the technical (Akrich 1992). Moving away from an individual conception of entrepreneurial initiatives, STS have also shown that opportunities are not merely discovered or speculated about, but result from collective exploration and creation (Garud and Karnøe 2003, Doganova 2009). Partnerships are key, and they are constituted through negotiations and trials in which material and cognitive devices intervene. Trials are defined as tests and experimentations, often involving translations and displacements, at the outcome of which a project gains or loses reality, i.e. comes closer to, or moves further from existence depending on whether it has managed to adapt or not (Coutouzis and Latour 1986, Doganova 2009).

What does this imply for the study of community projects? First, it invites to consider the community and the project as a single entity, without distinguishing between its technological, social and economic characters: these are taken to be shaped together, even when the project grafts on a pre-existing community and its network. Local 
capacities also are constituted through trials and translations, and the modalities of their organisation (here, mutualisation) are not a pre-given blueprint but have to be negotiated and adjusted along the way.

Second, this requires to expand the scope of innovation studies. Literature on technology, innovation and entrepreneurship is mostly interested in how innovations become competitive and move from niches to the mainstream (Hargreaves et al. 2013, p. 868). Yet, innovation can serve other purpose and strive to reconcile multiple values (Doganova and Karnøe 2014). This is particularly true of grassroots innovation. ${ }^{3}$ As Haggett and Aitken (2015, p. 99) emphasise, community energy projects have multiple benefits (for communities, the environment, or renewable energy development, for instance). Besides, they often are not limited to "using greener technologies", but also involve "experimenting with social innovation" (Seyfang and Smith 2007, p. 585), which has received little attention from innovation studies. Thus, they challenge the tendency to consider innovation as aiming for "growth, diffusion and mainstreaming" (Hargreaves et al. 2013, p. 878).

The project studied here is purportedly innovative, but its objective is not to conquer market shares or to be mainstreamed; it is expected to yield financial income, as well as new activities and skills, possibilities for redistribution, environmental values associated with renewable energy production, and territorial regeneration and solidarity. So, my description of its coming into being is not just about understanding how innovative projects are realised; it is rather about understanding what enables a group or a community to create and realise an opportunity in a "territorial", "community", redistributive, but also innovative and entrepreneurial way, and how the territory and the community are redefined by and through a project.

Empirical material was collected in 2013, five years after the beginning of the project and two years after its completion. Table 1 summarises the timeline of the project. Fieldwork was carried out in the office of the Fermes de Figeac, the cooperative which started the project. It consisted in visits to photovoltaic installations, discussions with staff, interviews, and consultation of archives. Fourteen semi-structured interviews were recorded and transcribed: two with staff in the cooperative; seven with farmers part of the administrative council of the firm that operates the photovoltaic park (including its president); and five with partners that intervened at various stages in the project (banker, legal counsellor, utilities, local administrations, PV installers). ${ }^{4}$

The objective of fieldwork was to identify and understand the trials that the project went through, that is to say the moments of uncertainty and negotiations when its future was at stake. I also looked for traces of the links, entanglements and partnerships at play, and of the devices and methods of valuation that were mobilised to create and sustain

${ }^{3}$ I use the term "grassroots innovations" as defined by Seyfang and Smith (2007 p. 585) "to describe networks of activists and organisations generating novel bottom-up solutions for sustainable development; solutions that respond to the local situation and the interest and values of the communities involved."

${ }^{4}$ Interviews were translated from French. Details are provided as an appendix. 
them. Interviews provided detailed accounts of the trajectory of the project and of key moments in its realisation, ${ }^{5}$ while archival work gave access to written traces of negotiations and trials, as well as to some of the paper devices that hold the project together (contracts, business plans, technical guarantees, characterisation of rooftops, lists of shareholders, etc....). I paid close attention to three elements that make the project distinctive: first, its articulation to the policy and market framework as it was then defined by feed-in tariffs; ${ }^{6}$ second, the relationship of the cooperative, and of its project, to its territory, understood as a geographical, patrimonial and social entity; and last, the organisation and role of mutualisation, which appears as a strong ambition and a key driver in the project.

Table 1. Timeline of the project

\begin{tabular}{|l|l|}
\hline 1985 & Creation of the cooperative "CASELI" (now Les Fermes de Figeac) \\
\hline July 2008 & $\begin{array}{l}\text { Creation of Ségala Agriculture et Energie Solaire, the legal entity in charge } \\
\text { of the PV project }\end{array}$ \\
\hline November 2008 & Deal signed with Tenesol for PV systems installation \\
\hline June 2009 & All purchase agreements signed, FITs secured at $60 € \mathrm{c} / \mathrm{kWh}$ for all \\
\hline July 2009 & Agreement of principle from banks; installation work begins \\
\hline June 2010 & Loan convention signed in Paris \\
\hline March 2011 & Last PV systems connected to the grid - project completion \\
\hline June 2012 & Extension of the SAES social object to include all kind of RE projects \\
\hline March 2013 & New mutualised PV project launched \\
\hline
\end{tabular}

\section{The collective as a project}

Research on community renewable energy has noted that projects fare better in places with pre-existing networks, institutions and capacities for community action (Walker et al. 2009, Seyfang et al. 2013, Hargreaves et al. 2013, Haggett and Aitken 2015). In that respect, the project considered here emerged on fertile grounds. It was led by the Fermes de Figeac (Figeac Farms), an agricultural supply cooperative based in Lacapelle-Marival, in the Lot, a rural département in the south-west of France. The cooperative's reach is limited to an area named Ségala-Limargue (Fig. 1a and 1b).

${ }^{5}$ Interviews took place after project completion and with some of the most actively involved participants, potentially inducing a bias: past conflicts and tensions might have been downplayed or forgotten in accounts. That such tensions are not described in detail here thus does not imply that they did not occur, but suggests that if they occurred, they were resolved or, at least, did not undermine the project.

${ }^{6}$ Feed-in tariffs are widespread instruments for supporting renewable energy production in Europe. Under a feed-in tariffs scheme, utilities have to purchase electricity from renewable energy sources, and price and duration of purchase agreements are set by public authorities so as to ensure the viability of investments (Mitchell et al. 2011). 


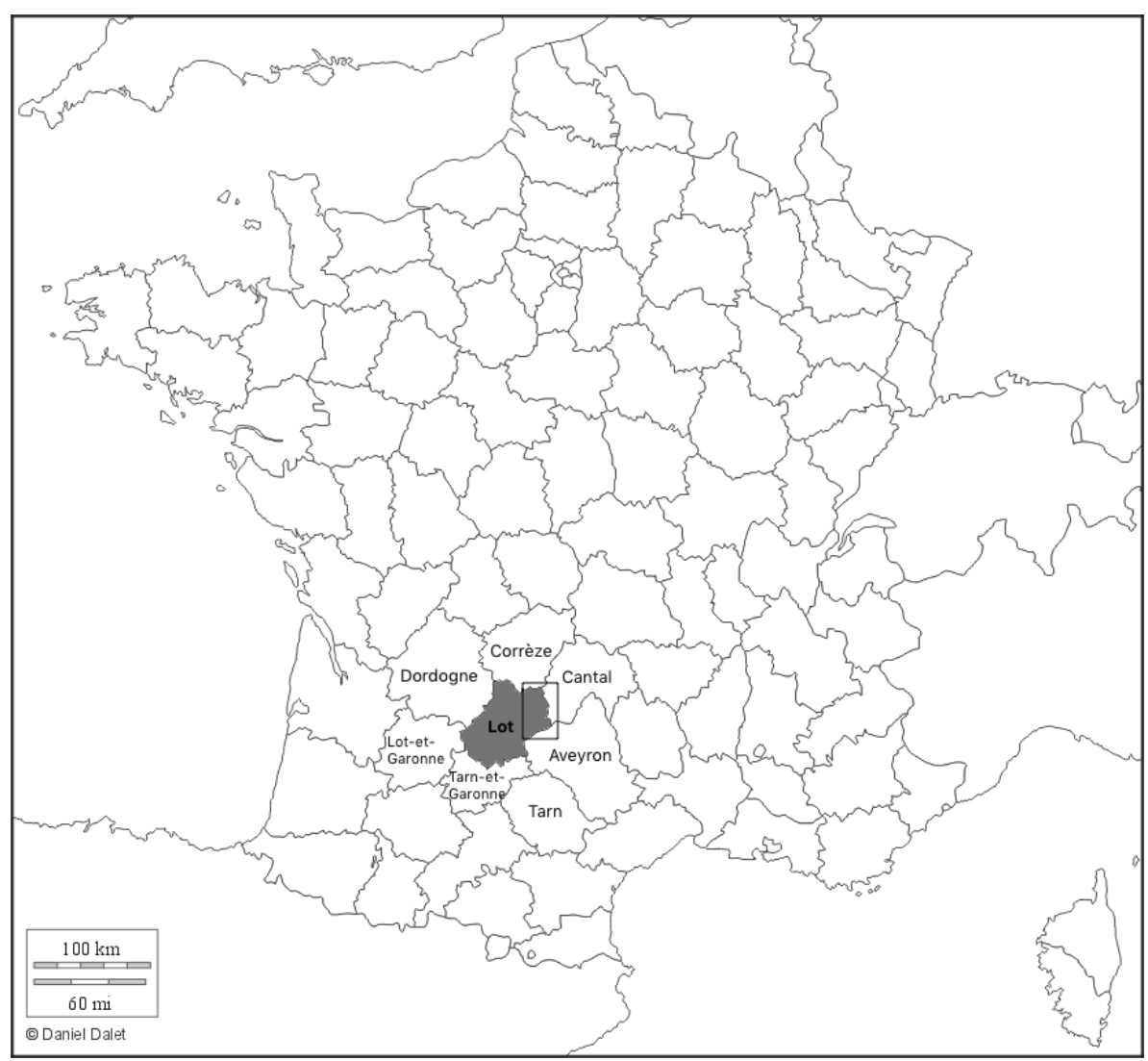

Figure 1a. Location of the Lot and nearby départements. Base map from histgeo.acaix-marseille.fr (accessed 4 January 2017), modified by author

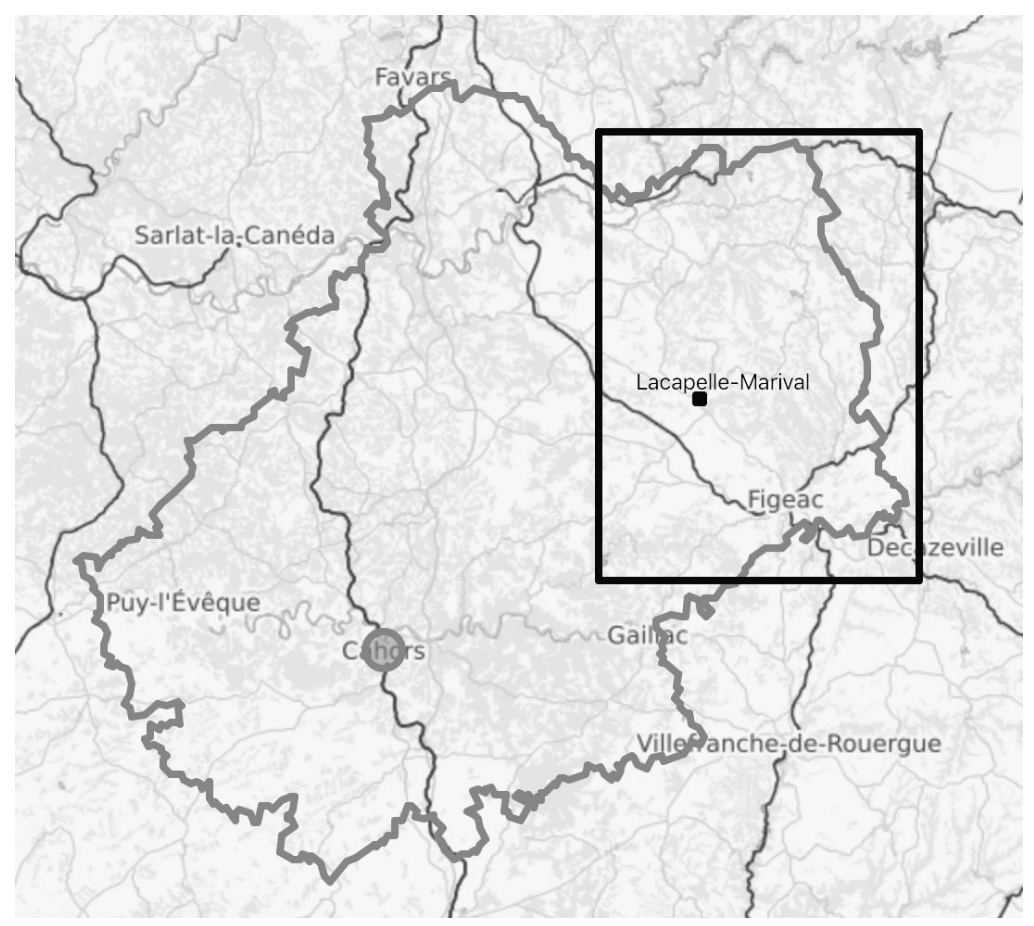

Figure 1b. Map of the Lot (openstreet map). Grey line indicates the limits of the Lot, black square shows approximately which part of it is Ségala-Limargue. The cooperative headquarters are located in Lacapelle-Marival. 
It is an area of small villages and hamlets, mostly populated by small-scale livestock farmers and retired people enjoying the hilly and in some parts arid landscape. Farms are scattered but organised in dense, interwoven networks of cooperatives; as most farms are rather small, supply, sale, machines and materials are very often managed collectively. The Fermes de Figeac emerged in 1985 from this web of "solitary but solidary" farmers (Interview 12).

It started as a small venture, with a staff of 20 that has steadily grown to reach 120 in the 2010s (sicaseli.fr). It comprises of 650 members who are represented by and administrative board of 24 farmers and a president. It owes a large part of its dynamism to the leadership of its executive director and of its president, first elected in 1997. Interviewees praised them for their openness and entrepreneurship, and for their ability to hold the group together and to manage it in a transparent, collaborative manner, respectively (Interviews $1,5,7$ ). In addition to these two leaders, one employee of the cooperative, hired in the early 2000s after having worked on rural development in Senegal, was a driving force in the involvement of the Fermes de Figeac in renewable energy.

The Fermes de Figeac claims to have "one ambition: to become a territorial cooperative" (sicaseli.fr). It develops its activity as a way to respond to current challenges faced by the region. The regional agricultural fabric is threatened by heightened competition from more productive regions. It suffers from dependence on large retailers and from the increasing volatility of cereal and raw material prices. Farmers are growing older and decreasing steadily in numbers, a trend that is expected to continue. This goes along with an overall decline in population and activity in the area, and is a threat to the preservation of a landscape shaped by agriculture and livestock. From its infancy, the cooperative inscribed its action in Ségala-Limargue, and is deliberately "locked into a territory" (Interview 2). Its prospects are thus intimately tied to those of the territory, and it is vitally confronted to the same challenges.

Its strategy in coping with them has been to articulate collective action, territorial regeneration and innovation as interdependent. Its objective to "contribute in the long run to the promotion of a high added-value agriculture that manages the living and is innovative and open, so as to take part in sustainable development for all from our territory" (sicaseli.fr) is developed in a set of written values that serve as a matrix for action and an actualisation of the cooperative history. Among others, the cooperative emphasises "collective solidarity as the basis for collective action" and "innovation as a necessity to keep local know-how and culture alive" (sicaseli.fr). These are not abstract principles set in stone, but very practical values that are carefully maintained and continuously re-enacted in the cooperative's organisation and projects. The president stresses that collective dynamics cannot be taken for granted and require time and dedicated work, involving discussions and reformulations of the cooperative's values, time to create adhesion and strive for unanimity in decisions, and space for people to express themselves (Interview 9). Similarly, the territory is not considered as a set heritage to preserve, but as an ever-adapting "space of resources" and "space of partnerships" that binds people and natural entities together in a common future (Olivier 
2013). Indeed, the cooperative director claims, "we need to adapt continuously. Only through mutualisation will we manage to do it sustainably. The territory unites us once and for all" (Olivier 2013). Innovation is thus not limited to the development of new products and processes, but is a means of adaptation and even survival through the development of new technologies, new business models, and new activities as sources of value.

When the Fermes de Figeac claims on its website that it "has developed along with its territory, making the most of its progress and supporting it through a continuous search for innovations", it refers to very concrete past and ongoing achievements. Though supply remains its main activity and source of income, the cooperative has gradually invested in other activities: direct sales, consulting, supply of building materials, service provision. This diversification enabled it to create and strengthen ties with other local cooperatives, banks and businesses, as well as with local governments and public agencies. This reinforced its public image as a cooperative focused on the promotion of territorial agriculture, established it as a credible and reliable economic actor, and gave it access to information, expertise, ideas and partnerships.

As part of this strategy and relying on these networks and resources, the Fermes de Figeac has nurtured an interest for renewable energy as a potential path for development since the beginning of the 2000s. It set up a team to follow policy evolutions and took part in visits organised by the $\mathrm{ADEME}^{7}$ in France and abroad (Interviews 2, 9). The photovoltaic project was inspired by an encounter with another cooperative in nearby Aveyron. Relying on feed-in tariffs that were in place in France, this cooperative had developed a collective photovoltaic park, installing photovoltaic panels on farm roofs and mutualising both administrative work and financial benefits - an unprecedented initiative in France.

In 2008, feed-in tariffs, which guarantee that electricity from renewable energy sources will be purchased at a price higher than the market price, were very high for photovoltaics in France (Cointe 2015, 2017). Rural photovoltaics were a profitable business, and farmers in the Lot were canvassed by prospective developers seeking to rent large rooftops to install solar panels. Putting together this unexpected resource - vast surfaces of sunlit rooftops - across the territory appeared as a promising idea for the Fermes de Figeac. The idea of a mutualised photovoltaic park on buildings stemmed from a will to ensure that the territory - as a geographic area and as a group of people - would benefit from photovoltaics and from feed-in tariffs. The project was innovative in that it sought to develop a new domain of activity, but also in its organisation. Mutualisation was crucial, because it permitted to distribute revenues and to pool resources (time, expertise, trust) to deal with project elaboration and realisation. As a result, it could "enable all types of farmers to benefit from [the project], not just the big ones" (Interview

7 The Agency for Environment and Energy Management (ADEME) is a public institution under the control of the Ministry for Ecology. It contributes to the implementation of environmental and energy management policy, and provides expertise and public information on environmental and energy issues. 
4). The ambition of mutualisation and its effective organisation can thus be understood as enacting a conception of equity and solidarity as rooted locally and supported by innovation. It does so relying on feed-in tariffs and turning them into tools for territorial development and redistribution of a newly attractive solar resource.

\section{The project as a collective}

The idea that started the project was to gather owners of farm buildings with large roofs, to install photovoltaic systems on these roofs, to sell the electricity generated at the feedin tariff, and to redistribute this income as rents and dividends. Installed photovoltaic panels would thus be pooled together, and each participant would get the same amount for each square meter of roof surface made available (Table 2). Turning this idea into an actual photovoltaic park tied to a local community of farmers required significant work. The process was steered by the president of the Fermes de Figeac and the employee mentioned above, and by the administrative council of the company created to operate the park.

\section{Table 2. The project in a nutshell}

- A company, the SAS Ségala Agriculture et Energy Solaire (SAES), is created to operate the park; shares are owned by participants in the project, as a proportion of the surface they make available for photovoltaics.

- Shareholders as a whole contribute $20 \%$ of the amount needed. The remaining $80 \%$ is funded by banks through a loan.

- SAES rents roofs, pays for the installation of PV systems, takes care of administrative tasks, and sells the electricity generated to EDF via the feed-in tariff mechanism.

- The project is expected to yield mean annual benefits of $20 € /$ square meter of PV panel/year over 20 years. Benefits are redistributed to participants as dividends in addition to the rents they receive.

- Each participant gets the same amount for $1 \mathrm{~m}^{2}$ of PV panel installed on a roof they owned, regardless of variation in production across installations.

In this process, not only the roofs were transformed, but also the cooperative, and, to a certain extent, the participants in the project and the territory. At every step of the way, the material, social and organisational aspects of the project were all under trial, and all were shaped and transformed by the work of carrying the project forward. The outcome was the creation of a photovoltaic park scattered across the land, as well as of a renewed community defined by its links to the park. Both the cooperative and the territory got gradually entangled in new networks, some of which reach far beyond SégalaLimargue. In this section, I examine three concomitant challenges, the trials and transformations that they involved, and the devices that were mobilised to face them. I focus on these challenges because they were critical for the success of the project, and because they cover the main aspects of mutualisation. 
The assessment and development of the project required to frame it, that is to draw a boundary between the entities and relations that would be taken into account in its realisation and in the calculations relative to it, and those that would be ignored (Callon 1998). As Doganova (2009, p. 34) noted, framing is not only an intellectual or symbolic operation, but involves equipment. It is not straightforward and usually produces overflows.

As the core idea was that each participant in the project would bring in a surface of well-exposed rooftop, the project and the group carrying it out were necessarily framed together. The potential of the project in terms of energy production and of economic benefits, and, before that, its very possibility, first depended on the successful enrolment of roof owners. It was further configured by the organisation of the relationships among all the human and non-human participants in the project. One of the first challenges was thus to assemble a collective resource.

\section{Selection of roofs and participants}

The number of participants and the localisation of their rooftops directly determined the feasibility and viability of the project. The first step in the transformation of the Fermes de Figeac's idea into an actual photovoltaic park was to inform and recruit roof-owners. This proved easy: many farmers were well-aware of the opportunity constituted by feed-in tariffs for photovoltaics at the time, and the letter sent by the Fermes de Figeac to its members in the spring of 2008 to present the idea was met with unexpected enthusiasm: over 300 people attended the first information meeting (Interviews 2, 11). The cooperative then asked those interested in the venture to fill in standardised statements of intent, and received 270 of these, for a total of 500 roofs (Tenesol and Sicaseli 2010). This points to enthusiasm for photovoltaics and trust in the cooperative, but also to a commitment to mutualistic values across the territory, as farmers could have chosen to go at it alone.

The availability and quantity of the resource was thus not a problem, but the potential of the project depended on its quality as well. The definition of required qualities was part of the framing, and it was refined along the way. Roofs and farmers were selected according to several criteria:

- First, the access they provided to the solar resource, in terms of exposure to sunlight, of course, but also depending on the possibility to connect potential photovoltaic systems to the electric grid at a reasonable cost;

- Second, the material and legal capacity of roofs to become photovoltaic electricity generation units. This depended on their physical capacity to support the weight of solar panels, on obtaining construction permits, and on the possibility to reframe property rights in a way compatible with the project structure (cases of joint ownership could be problematic); 
- Third, the financial viability of their inclusion. This chiefly depended on the ability of owners to bring their share in the funding of the project, and/or to obtain loans to do so, but also on grid connection fees not being too high.

The information provided in the statements of intent allowed for a first selection: it included an inventory of building characteristics, legal and administrative details, situation of roofs in relations to the electric grid, and sketches of proposed buildings in their environment. This selection was refined throughout the realisation of the project. Some buildings were excluded after detailed technical studies by the firm in charge of installing solar systems; some because they failed to obtain construction permits from the municipality; some because their owners failed to secure loans to contribute to the venture, or to renegotiate property rights as needed; some because of high grid-connection fees that threatened the viability of the project as a whole; and a few because their owners chose to leave the project. The composition of the prospective park was readjusted at virtually every step of the way, with compromises having to be reached about individual buildings to ensure the viability of the group. The perimeter was not stabilised until December 2010.

\section{Creation of a company}

The framing of the project was guided and justified by the commitment to mutualisation and by the framework provided by feed-in tariffs. At first glance, this dual commitment could seem contradictory. Feed-in tariffs were designed for individual investors, so the project needed to organise to combine a mutualised approach with the creation of a single legal and economic entity in charge of park operation and administration. Crucial issues ultimately pertaining to a definition of equity and solidarity needed to be addressed in practical terms: what should be pooled together, and what should be excluded from mutualisation? How should it be put and kept together?

These issues were at stake in the creation of the company that would operate the park, trade the electricity, and take care of administrative work. In this process, the Fermes de Figeac were assisted by legal counsellors who helped navigate the range of possible organisational choices and their consequences. They eventually opted for a simplified joint-stock company, which is not a cooperative structure but works in a similar fashion, with a president and an administrative council (Interview 6). The initial plan was to restrict the geographical perimeter to the area of Ségala-Limargue, but given demands, it was eventually agreed to include outlying buildings (Interview 11). Participants were asked to contribute to the investment by buying shares so as to put in $20 \%$ of the funds needed to equip the roofs they made available. To maintain the territorial character of the project, share-ownership was bound to the buildings: only people related to these buildings are entitled to hold shares, and shares cannot be sold without the administrative council's agreement (SAS SAES 2008, article 8).

Organisational choices account to an extent for the selection of participants. Shares were dependent on the roof area brought in by participants, so both investments and profits were levelled according to this criteria: differences in installation costs or production would ultimately not affect individual gains, so they could not be too wide if 
the venture was to be viable. Grid connection fees were mutualised, so they had to be relatively homogeneous: roofs that would cost more than $20 \mathrm{c} / \mathrm{Wp}$ to connect were excluded (Interview 4). ${ }^{8}$ Uniform conditions were negotiated for all individual loans financing the participants' contributions. To smooth out gains across roofs, it was also important that each installation secured feed-in tariffs at the same level. The SAES, and the creation of a small team devoted to the project within the Fermes de Figeac, thus constituted an individual agency able to fit the feed-in tariff framework and to manage the administrative procedures required to set up a project, connect installations to the grid, and secure feed-in tariffs.

The company was closely tied to the Fermes de Figeac, who held shares, was represented in the administrative council, and provided manpower. Both entities had the same president. This was instrumental in ensuring group cohesion, as the SAES benefited from the trust that participants already had in the cooperative and from its competences and its experience with collective work. The relationships between the small team piloting the project and the larger group had to be carefully orchestrated, and the president was well aware that this required constant work and attention. He relied on "transparency, solidarity - mutualisation -, competency and effectiveness" (Interview 9), which translated in very practical terms. While a small team was entrusted to carry out negotiations and administrative procedures, key choices were made by an administrative council which had been constituted to be representative of the diversity of participants. They were cautious when drafting the business plan and selecting participants and partners. This was necessary to keep the backing of the cooperative, whose executive director was at first wary, given the financial and symbolic risks. Last, the commitment to transparency translated in regular meetings, in availability of information, and in openness about challenges and difficulties (Interview 9). This strategy apparently enabled the group to hold together throughout the trials and hurdles of the project, despite a couple of conflictual cases (Interview 9).

\section{Turning rooftops into solar power plants}

The constitution of the group and the delimitation of the perimeter of the project largely relied on existing local structures, capacities and resources. Most participants were members of the Fermes de Figeac; the project used roofs that had been around for a while; and the cooperative's reputation, staff and experience provided the basis for collective organisation and cohesion. All the same, while building on an existing community and territory, the project involved their renewal and reconfiguration. The territory was to become an electricity-generating area, via the transformation of farms roofs into solar plants. This transformation was manifold and enacted through material operations, paper trials and partnerships that were all new for the cooperative.

\footnotetext{
${ }^{8}$ Interviewees stress the opaqueness of grid-connection fees that could differ widely from one roof to the next, and that they perceived as arbitrary (Interviews 10,11).
} 
To become "sites for the production of electricity from the sun's radiative energy (photovoltaics)" operated by Ségala Agriculture et Energie Solaire (SAS SAES 2009), roofs first had to be disentangled from their buildings and owners. This involved their separation from the rest of the building on cadastral plans, and the writing and signature of leases which gave legal consistence to the new relationship between the SAES company and the buildings. They also put them collectively into the care of the same actor, enacting de facto their inclusion in the same project.

The signature of leases was the first step towards the re-entanglement of roofs into another, much larger network of relationships: the electricity grid and market. This reentanglement, though steered by the cooperative staff and the SAES administrative board, required partnerships and negotiations of different sorts, with a firm in charge of the supply and installation of photovoltaic systems (Tenesol), but also with regional stateservices (DREAL), grid operator (ERDF) and electric utilities (EDF AOA). Organising these relationships required work in itself, given the number of files that had to be processed within the project (one for each installation, i.e. for each roof); it was more or less easy depending on the partners and on the possibility to have one dedicated interlocutor.

The re-entanglement process of course involved the actual installation of photovoltaic systems on the roofs, which was managed by Tenesol - a significant operation in itself. It took "twelve months of construction work, including six months at full load, with a mean of 25 sites simultaneously" to uncover roofs, often remove asbestos and/or reinforce building frames, and eventually install photovoltaic systems partly assembled in Tenesol's factory in Lyon (Tenesol 2010). But the physical transformation was only one part of a process that also involved the connection of roofs to the electricity grid and market.

Grid-connection is as much an administrative as a material operation. Procedures vary according to installation size, and involve technical and financial studies. Material connection can be more or less complicated and costly depending on the site. Gridconnection also requires to have signed a purchase agreement, that is to say to provide proof of the inclusion of the future installation in the electricity market, so as to ensure that the electricity injected in the grid will find a purchaser. Purchase agreements are signed with EDF-AOA, a branch of EDF based in Lyon and operating at the national level (as opposed to grid-operators, who have regional divisions), after a lengthy process requiring several administrative documents. For this, the SAES could not deal with one dedicated contact point, as it had done for other procedures, and had to wait for each request to be processed individually.

While the SAES administrative council and the Fermes de Figeac staff coordinated the process, the disentanglement and re-entanglement of roofs was largely a case-by-case matter. Throughout 2009 and 2010, installations progressed individually, each at its own pace. The park started operating as soon as the first system was ready, but did not exist in its collective, stabilised form until the last installation was connected to the grid in March 2011.

At this point, the roofs had been fully disentangled from their previous use and reconfigured as parts of a photovoltaic production park scattered across the area. This 
transformation of roofs in turn altered the community and the territory. The cooperative and the participants in the project have learned a new trade to become electricity producers on top of being agricultural actors (Interviews 4, 11). The Fermes de Figeac's staff now includes a small team dedicated to monitoring and maintaining the photovoltaic park. This team has developed a precise knowledge of the park, by visiting each installation but also thanks to an informational infrastructure that provides production data for the whole park. Each installation is connected to the internet and sends live information and daily report on its production and functioning, which is processed using dedicated software. This makes it possible to track production almost in real-time, to detect discrepancies and potential malfunction, and when need be, to alert farmers and ask them to check their installations via a text-messaging system.

The territory itself gained new qualities in the process: the existence of the collective photovoltaic park has led to creation and handling of new data, drawing attention to geographical characteristics that were not systematically considered, and resulting in the emergence of a new picture of the land in terms of local variations in sunshine (Interview 4). This denotes the successful integration of the photovoltaic park in the territorial fabric of the territory and in the daily life of farmers: it is routinized, stabilised and familiar. It is also fully integrated in the activities of the cooperative, which now embraces renewable energy as a full part of its activities. The realisation of the photovoltaic park indeed provided it with financial, organisational, social and technical resources to pursue other renewable energy projects and experiment with diverse technologies (wind power, biomass...).

\section{Negotiating financial viability}

Up to this point, the relations, trials and reconfigurations that I described mainly took place at a local level. Yet, local entanglements are not enough to give account of the project, especially when financial aspects are considered. Contrary to most of the Fermes de Figeac's activities, the business model of the photovoltaic project and its financial scope required its entanglement in networks and partnerships that reached far beyond its region.

\section{Negotiations with banks}

The project relies upon the return on investment guaranteed by feed-in tariffs - in 2008, when the project started, feed-in tariffs for building-integrated photovoltaics in France amounted to 60 eurocents/kWh, promising more than reasonable returns. Feed-in tariffs do not favour cooperative or community projects a priori: as Hargreaves et al. (2013, p. 871) have noted, they imply that community groups "have to adopt more business-like models, whereby they generate investment capital from sources other than grants". As the Fermes de Figeac largely counted on banks to fund the project, success hinged on their capacity to demonstrate that mutualisation within the feed-in tariff system was a viable business model. 
The promoters of the project and the farmers involved appeared rather confident in this viability, though the director of the Fermes de Figeac was initially reluctant, judging that it represented significant risks for the cooperative's finance and credibility. They considered their business plan to be cautious, as a result of long-term calculations and projections based on a conservative estimate of the solar resource. They had selected a financially solid partner for the provision and installation of photovoltaic systems: Tenesol existed since the 1970s and was then owned by EDF and Total. The endeavour was relatively secure as long as the project could benefit from feed-in tariffs: after all, it was backed by the Sun and the State, two virtually infallible guarantors if unfamiliar associates (Interview 6). Besides, mutualisation was meant to reinforce security by increasing efficiency and by sharing risks. All the same, it was an adventurous project of unprecedented scale. The investment was considerable: it neared 34 million euros, a sum that neither the Fermes de Figeac nor Tenesol had ever worked with.

Bankers were asked to contribute $80 \%$ of this amount, and their limited experience with photovoltaics made them hard to enrol. Though SAES had embraced the financial dimension of the venture and organised mutualisation as a key guarantee in the business model, their assessment of risks did not convince banks. Difficulties in negotiating funds were twofold. First, for bankers, large-scale mutualisation did not imply less risks, but more work (Interview 8). They had to assess the viability of each installation individually, and there were over 100 of them. Second, the investment was so important that it could not be borne by one bank, and even less so by the regional bank that the Fermes de Figeac usually worked with. The project required the constitution of a syndicate loan with banks that were not necessarily connected to the region and had little to no experience with photovoltaics, so were all the warier. Syndicating this loan required long financial and legal negotiations (Interview 8).

What was at stake was the translation of the Fermes de Figeac's proposal - and in particular, of the value of mutualisation - in financial terms. It was probably the most trying step in the project: only financial aspects mattered to the banks, who did not take into account the multiple benefits of mutualisation and the redistribution of profits, but also of risks and responsibilities that it enacted. The negotiation of the loan convention occurred during the installation of the park, but in many respects, it was set on a different plane, scale and timeframe. Negotiations no longer took place among actors with a direct relationship to the territory and the community, but involved national-level actors in faraway offices. As one farmer stated:

\footnotetext{
"When you head up to Paris, when it is a subsidiary branch [of the regional bank that you usually work with], they no longer know anybody. You may as well be with [any other bank].” (Interview 1)
}

The syndicate loan indeed involved regional and national banks, and, faced with very tense negotiations, the Fermes de Figeac sought support from the national federation of French cooperatives, who intervened with a letter. The project was abstracted to be assessed by financial analysts and lawyers who had never set foot in Ségala-Limargue and relied on documents pertaining to the characteristics they deemed relevant. 
Negotiations stretched on for one long and stressful year, while Tenesol was installing the park and awaiting payment. Temporalities seemed almost irreconcilable, and the stakes were high. The loan convention was eventually signed in a Parisian office with a view over the Champs Elysées - miles away from the actual park, and worlds away from it as well.

\section{Long-term viability}

The negotiation of funds was a determining power play and, had it failed, the project would have collapsed. However, it was not enough to ensure long-term profitability and territorial benefits. This last - but lasting - trial contributed to shape the organisation of the mutualised park. Mutualisation means that participants are collectively and individually responsible for their own earnings, which depend on the good functioning of each and every installation. It can thus contribute to the sustainability of the project; but it is not a guarantee in itself. The Fermes de Figeac and SAES organised maintenance so as to secure and maximize profits even if some participants did not live up to their responsibility. The maintenance team knows the territory, the park and the participants well, and is thus able to react swiftly when there are problems. Whereas an outsider firm would maintain the park to a level of production anticipated in its contract, the Fermes de Figeac has higher standards because it always seeks to maximise production. As the president explain, "the difference comes from these additional 3 to $4 \%$ that very often make the profit. And you [get them] through proximity, competence and reactivity. And that's one of the strengths of the collective: we have the right perimeter to offer such maintenance" (Interview 9). However, contrary to what this quote may suggest, this "strength of the collective" is not to be taken for granted: it is the outcome of organisational choices and of their enactment in practice - which involves people, intangible elements (familiarity with the territory, attachment to the cooperative, shared values, fair inclusion in the process), and devices (adapted software, or a cleaning robot conceived specifically for the park) (Interviews 4, 10, 11, 12).

\section{Conclusions}

Here, I have analysed a local renewable energy project as an innovative and entrepreneurial venture driven not only by economic motives, but by a concern for inclusion, solidarity and sustainable territorial development. I have focused on mutualisation as a way to pool together, strengthen an expand practical capabilities and values. Adopting a relational perspective to describe how mutualisation was organised in practice, I have shed light on the operations through which justice and equity concerns can be incorporated in renewable energy projects framed by market-based policy support, and on the tensions that may arise in the process. Justice and equity are not explicit objectives of the project, but because of the choice of mutualisation as a way to broaden access to renewable energy production, to share resources and to distribute financial profits, they are crucial to the viability of the project and its community. The project thus implements a conception of inclusion, solidarity and equity without which it cannot hold. 
A first observation, in line with the literature, is that the project and its community did not emerge out of nowhere and nothing. They relied on a very attractive support policy - though one that did not specifically target community energy - and grafted on the previous and ongoing work of the Fermes de Figeac cooperative to root its activity in a territory, develop collective methods, and find new resources to revive and sustain the local rural fabric. Most of the elements that Seyfang et al. (2013, p. 980) identified as critical success factors for community projects (key committed individual, effective group organisation, skills, money and material resources, trust with community, supportive partnerships and information-sharing network, supportive national policy context) pre-existed the project and made it possible. The choice of mutualisation itself stemmed from a mutualistic tradition and from long-held values of a cooperative that views territorial development as dependent on collective action and innovation. This does not mean that the community was taken for granted and that it did not have a transient, dynamic character (Walker et al. 2009). Rather, the photovoltaic project was part of a broader effort and relied on values, skills, expertise and people that had emerged over the years and that the leaders of the cooperative carefully worked to sustain and renew.

However, the solar park did not emerge directly from these pre-existing capacities and resources. They made things easier but provided no guarantees of success. I have retraced the many trials, displacements and adjustments that the project underwent during its realisation. Each put its success at stake. They shaped the project, but they also transformed the group, capacities, networks and resources that pre-existed it, and created new ones (Interview 9). As I have described, they played out on different levels, involving very concrete and local studies and transformations of rooftops as well as abstract negotiations among bankers and lawyers.

By retracing them, I have also described the practical work deployed to implement a conception of justice, solidarity and equity in a project, and thereby to reinterpret a policy device intended to accelerate the large-scale deployment of photovoltaics without incorporating concerns over territorial redistribution or equity. Mutualisation implies that this conception is as important as financial considerations for the viability of the project. Yet, this conception did not naturally fit in the institutional and policy framework, and I have shown that it created tensions over the course of the project, as exemplified by the selection of participants, the management of grid connection individually, or the long negotiations with banks. The conception of feed-in tariffs and solar resources as something that could be mutualised so as to enact and reinforce values of locality, solidarity and community was not provided for by established procedures. It even clashed with them, in some instances, as was the case with banks.

Last, the description of these trials and entanglements results in a picture of local projects as entangled in multiple scales and networks. They are definitely not reducible to their local character which is, in fact, protected and made possible by these wider entanglements. The Fermes de Figeac project is not contained locally: as a result of the constitutive choice to make the most of feed-in tariff policy, it relies on a connection to non-territorial networks embodied by grid-connection and purchase agreements. Similarly, the form of redistribution and inclusion that the project performs is supported by its entanglement in a policy framework and a funding arrangement that take no 
consideration of the collective dimensions and non-economic aspects of renewable energy projects, but are ultimately made to contribute to them. Through the purchase agreement and the feed-in tariff scheme, the photovoltaic park is connected to the national electricity grid, to the mass market for electricity, and to national and European policy objectives. From the perspective of the cooperative and the farmers, photovoltaic production is intimately entangled into a community and territory that it transforms and revives; yet, as a result of its reliance on the feed-in tariffs, from the perspective of purchasers, the electricity produced and traded is of generic quality, virtually disentangled from its conditions of production. ${ }^{9}$

The fact that the cooperative and its project reached beyond their area of implantation was a crucial factor for success. While territorial in its design and aims, the initiative was not just about using a policy incentive to harvest a newly valuable resource locally, but also about articulating the objectives and values behind the project to broader concerns and ambitions as framed by national renewable energy policy and, specifically, feed-in tariffs. As I have noted, this frame is largely market-oriented, but it also rests upon a longstanding conception of electricity as a public service embedded in price-setting practices (Yon 2014): the levy on electricity use that finances feed-in tariffs also serves to fund the equalisation of electricity costs across regions and state aids to guarantee basic access to electricity to the poorest. The project is thus not just about integrating equity concerns into a market-based instruments, but about conciling two different conceptions of equity and modalities of redistribution. The entanglement of the cooperative and its territory within energy markets and policy and with other conceptions of energy justice was a condition for the production and distribution of new local capacities and resources.

In many respects, the project was contingent on a very favourable set of local and non-local conditions, and it is not directly replicable. It still serves as an inspiration and a toolbox for future projects in Ségala-Limargue and elsewhere. An ANT-inspired account of the way solidarity, community and territory were entangled to economics and renewable energy innovations highlights the many small experiments and adjustments that enabled a local cooperative to take part in the big business of electricity production in a manner devoted to solidarity, locality and community. One could argue that it is precisely from these that lessons can be drawn and, perhaps, transferred.

\section{Acknowledgments}

This work was supported by the French National Research Agency (ANR) under the program "Sociétés innovantes" [Grant number 2011- SOIN-003-01, project "COLLENER"] and by the Regional Council Ile-de-France, DIM R2DS [Grant number2010-13].

${ }^{9}$ The material and geographical characteristics of this electricity sometimes come back into play. One interviewee explained how a summer drought accelerated the connection of their photovoltaic installations: with less water, dams could not provide enough electricity for the region, and nearby photovoltaic production capacity was a welcome addition (Interview 1). 


\section{Appendix}

\section{List of cited interviews}

[1] Farmer, member of the Fermes de Figeac and SAES administrative boards, March 2013

[2] Executive director of Fermes de Figeac, October 2013

[3] Regional administration for environmental and land-planning (DREAL MidiPyrénées), January 2013

[4] Fermes de Figeac employee, de facto manager of the photovoltaic project, October 2012

[5] Farmer, participant in the photovoltaic project, Marche 2013

[6] Legal consultant, January 2013

[7] Farmer, member of the SAES administrative board, March 2013

[8] Banker, syndicate loan coordinator, April 2013

[9] President of Fermes de Figeac and SAES, March 2013

[10] Farmer, member of the Fermes de Figeac and SAES administrative boards, March 2013

[11] Farmer, member of the Fermes de Figeac and SAES administrative boards, March 2013

[12] Farmer, member of the Fermes de Figeac and SAES administrative boards, March 2013

\section{References}

Akrich, M., 1992. The de-scription of technological objects. In: W.E. Bijker and J. Law, eds. Shaping Technology/Building Society, Cambridge, MA: The MIT Press, 205-224

Akrich, M., Callon, M. and Latour, B., 2002a. The key to success in innovation, part I: the art of interessment. International Journal of Innovation Management, 6 (2), 187-206.

Akrich, M., Callon, M. and Latour, B., 2002b. The key to success in innovation, part II: the art of choosing good spokespersons. International Journal of Innovation Management, 6 (2), 207-225.

Amin, A., 2005. Local community on trial. Economy and Society, 34 (4), 612-633.

Catney, P., MacGregor, S., Dobson, A., Hall, S. M., Royston, S., Robinson, Z., Ormerod, M. and Ross, S., 2013. Big society, little justice? Community renewable energy and the politics of localism. Local Environment, 19 (7), 715-730.

Cointe, B., 2015. From a promise to a problem: the political economy of solar photovoltaics in France. Energy Research and Social Science, 8, 151-161.

Cointe, B., 2017. Managing political market agencements: solar photovoltaic policy in France. Environmental Politics, published online [http://dx.doi.org/10.1080/09644016.2016.1269527]

Coutouzis, M. and Latour, B., 1986. Le village solaire de Frangocastello. Vers une ethnographie des techniques contemporaines. L'Année sociologique, 36, 113167. 
Debourdeau, A., 2011. De la "solution" au "problème": la problématisaiton de l'obligation d'achat de l'énergie solaire photovoltaïque en France et en Allemagne. Politix, 2011/3 (95), 103-127.

Doganova, L., 2009. Entrepreneurship as a process of collective exploration. CSI Working Paper series, 17.

Doganova, L. and Karnøe, P., 2014. Clean and profitable: entangling valuations in environmental entrepreneurship. In: A. Berthoin Antal, M. Hutter and D. Stark, eds. Moments of valuation: exploring sites of dissonance. Oxford, UK: Oxford University Press, 229-248.

Garud, R. \& Karnøe, P., 2003. Bricolage versus breakthrough: distributed and embedded agency in technology entrepreneurship. Research Policy, 32 (2), 277-300.

Marvin, S. and Guy, S., 1997. Creating myths rather than sustainability: the transition fallacies of the new localism. Local Environment, 2 (3), 311-318.

Haggett, C. and Aitken, M., 2015. Grassroots energy innovations: the role of community owenership and investment. Current Sustainable/Renewable Energy Reports, 2 (3), 98-104.

Hargreaves, T., Hielscher, S., Seyfang, G. and Smith, A., 2013. Grassroots innovations in community energy: the role of intermediaries in niche development. Global Environmental Change, 23 (5), 868-880.

Latour, B., 2005. Re-assembling the social: an introduction to actor-network-theory. Oxford: Oxford University Press.

Middlemiss, S. and Parrish, B. D., 2010. Building low-carbon communities: the role of grassroots initiatives. Energy Policy, 38 (12), 7559-7566.

Mitchell, C., Sawin, J., Pokharel, G. R., Kammen, D., Wang, Z., Fifita, S., Jaccard, M., Langniss, O., Lucas, H., Nadai, A., Trujillo Blanco, R., Usher, E., Verbruggen, A., Wüstenhagen, R. and Yamaguchi, K., 2011. Policy, financing and implementation. In: O. Edenhofer et al., eds. IPCC Special Report on Renewable Energy Sources and Climate Change Mitigation. Cambridge: Cambridge University Press.

Moss, T., Becker, S. and Naumann, M., 2014. Whose energy transition is it, anyway? Organisation and ownership of the Energiewende in villages, cities and regions. Local Environment, 20 (12), 1547-1553.

Nadaï, A., Labussière, O., Debourdeau, A., Régnier, Y., Cointe, B. and Dobigny, L., 2015. French policy localism: surfing on 'Positive Energy Territories' (TEPOS). Energy Policy, 78, 281-291.

Olivier, D., 2013. Innover avec et pour le territoire. Fermes de Figeac, entre coopérative et nouvelles coopérations. PCM, 853, February, pp. 28-31.

Park, J. J., 2012. Fostering community energy and equal opportunities between communities. Local Environment, 17(4), 387-408.

Purcell, M. and Brown, J. C., 2005. Against the local trap: scale and the study of environment and development. Progress in Development Studies, 5 (4), 279-297.

Rydin, Y., Guy, S., Goodier, C., Chmutina, K., Devine-Wright, P. and Wiersma, B. 2015. The financial entanglements of local energy projects. Geoforum, 59, 1-11.

SAS SAES Solaire, 2008. Statuts de la SAS Ségala Agriculture et Energie Solaire. 
SAS SAES, 2009. Ordre du jour de la troisième réunion du conseil d'administration.

Seyfang, G. and Smith, A., 2007. Grassroots innovations for sustainable development: towards a new research and policy agenda. Environmental Politics, 16, 584-603.

Seyfang, G., Park, J. J. and Smith, A. (2013). A thousand flowers blooming? An examination of community energy in the UK. Energy Policy, 61 (4), 977-989.

Tenesol and Sicaseli, 2010. Parc solaire collectif photovoltaïque en milieu agricole. Un projet exceptionnel et exemplaire pour la coopérative Sicaseli et son fournisseur Tenesol. Press release.

Walker, G., 2008. What are the barriers and incentives for community-owned means of energy production and use?, Energy Policy, 36 (12), 4401-4405.

Walker, G. and Devine-Wright, P., 2008. Community renewable energy: what should it mean? Energy Policy, 36 (2), 497-500.

Walker, G., Devine-Wright, P., Hunter, S., High, H. and Evans, B. (2009). Trust and community: exploring the meanings, contexts and dynamics of community renewable energy. Energy Policy, 38 (6), 2655-2663.

Yalçin-Riollet, M., Garabuau-Moussaoui, I. and Szuba, M., 2014. Energy autonomy in Le Mené: A French case of grassroots innovation. Energy Policy, 69, 347-355.

Yon, G., 2014. L'économicité d'EDF. La politique tarifaire d'Electricité des France et la reconstruction de l'économie nationale, de la nationalisation au milieu des années 1960. Politix, 105, 91-115. 